\title{
Cloning of a Virulence Factor of Entamoeba histolytica Pathogenic Strains Possess a Unique Cysteine Proteinase Gene
}

\author{
Sharon Reed, * Jacques Bouvier, ${ }^{\star}$ Anna Sikes Pollack, ${ }^{*}$ Juan C. Engel, ${ }^{*}$ Margaret Brown, ${ }^{\star}$ Ken Hirata, * \\ Xuchu Que, * Ann Eakin, ${ }^{* 5}$ Per Hagblom," Frances Gillin, * and James H. McKerrow \\ * Departments of Pathology and Medicine, University of California, San Diego, California 92103-8416; Departments of ${ }^{\ddagger}$ Pathology and \\ \$Pharmaceutical Chemistry, University of California, San Francisco, California 94143; the" Department of Microbiology, University of \\ Uppsala, Uppsala, Sweden; and the 'Department of Veterans Affairs Medical Center, San Francisco, California 94121
}

\begin{abstract}
Cysteine proteinases are hypothesized to be important virulence factors of Entamoeba histolytica, the causative agent of amebic dysentery and liver abscesses. The release of a histolytic cysteine proteinase from $E$. histolytica correlates with the pathogenicity of both axenic strains and recent clinical isolates as determined by clinical history of invasive disease, zymodeme analysis, and cytopathic effect. We now show that pathogenic isolates have a unique cysteine proteinase gene (ACP1). Two other cysteine proteinase genes (ACP2, ACP3) are 85\% identical to each other and are present in both pathogenic and nonpathogenic isolates. ACP1 is only 35 and $45 \%$ identical in sequence to the two genes found in all isolates and is present on a distinct chromosome-size DNA fragment. Presence of the ACP1 gene correlates with increased proteinase expression and activity in pathogenic isolates as well as cytopathic effect on a fibroblast monolayer, an in vitro assay of virulence. Analysis of the predicted amino acid sequence of the ACP1 proteinase gene reveals homology with cysteine proteinases released by activated macrophages and invasive cancer cells, suggesting an evolutionarily conserved mechanism of tissue invasion. The observation that a histolytic cysteine proteinase gene is present only in pathogenic isolates of $E$. histolytica suggests that this aspect of virulence in amebiasis is genetically predetermined. (J. Clin. Invest. 1993. 91:1532-1540.) Key words: amebiasis • proteinases $\bullet$ cathepsins $\bullet$ pathogenicity $\bullet$ cytopathic
\end{abstract}

\section{Introduction}

Entamoeba histolytica infects more than 500 million people worldwide (1). Almost from the time of its discovery, it was observed that although $E$. histolytica most often causes mild or asymptomatic infections, $\sim 10 \%$ of patients develop severe dysentery and life-threatening invasive and extraintestinal disease (2). Whether these distinct clinical courses represent infection by two different species of Entamoeba (2) or, conversely, whether any strain of $E$. histolytica can potentially cause disease in the presence of certain environmental factors has been an area of active debate $(3,4)$. Distinct isoenzyme patterns (zymodemes) (5) and differences in restriction fragment-length patterns between pathogenic and nonpathogenic

Address correspondence to James McKerrow, Ph.D., M.D., Department of Veterans Affairs Medical Center, San Francisco, Anatomic Pathology Service-113B, 4150 Clement St., San Francisco, CA 94121.

Received for publication 7 May 1992 and in revised form 30 October 1992.

The Journal of Clinical Investigation, Inc.

Volume 91, April 1993, 1532-1540 strains (6-10) strongly support the premise that the potential to cause invasive disease is genetically determined. If virulence is genetically determined, we would expect a gene encoding a virulence factor that correlated with pathogenicity to be present only in pathogenic strains. We tested this hypothesis using the ameba cysteine proteinase.

Factors associated with the virulence of $E$. histolytica include surface lectins $(11,12)$, cytolytic ion channel-forming proteins (13-15), phospholipases (11), and proteinases (10, 16-18). The major proteinase of $E$. histolytica is a cysteine proteinase biochemically similar to cathepsin B (17-20). Experimental evidence supporting the role of this cysteine proteinase in the pathogenesis of amebiasis includes its ability to degrade fibronectin, collagen, and basement membrane matrix and to activate the third component of complement (17-19, 21). Purified proteinase reproduces the cytopathic effect of pathogenic amebae (17-20), and a specific irreversible inhibitor of the proteinase prevents destruction of cell monolayers by live axenic amebae (22). Increased expression and excretion of the proteinase correlates with virulence of both axenic laboratory strains of $E$. histolytica, and fresh clinical isolates $(16,19$, 20 ). Antibodies to the proteinase were detected in $83 \%$ of patients with invasive disease but were not detected in patients with noninvasive infections (16).

Eukaryotic cysteine proteinases have long been recognized as particularly potent proteinases but were best known for their role in intracellular protein digestion (23). More recently, evidence has accumulated that a subset of invasive cancers excrete active or activatable cysteine proteinases. A cathepsin L-like cysteine proteinase is the major excreted protein of transformed fibroblasts (24-26). Levels of cathepsin B were found to correlate with the metastatic potential of melanoma variants (24).

To determine whether the cysteine proteinase released by pathogenic $E$. histolytica is structurally related to those released by cancer cells and activated macrophages, we used polymerase chain reaction to identify and amplify genes encoding the cysteine proteinases of $E$. histolytica using primers based on conserved structural motifs of eukaryotic cysteine proteinases (27). We identified and sequenced three cysteine proteinase genes and now show that one gene is unique to pathogenic isolates of E. histolytica.

\section{Methods}

Strains of E. histolytica. Axenic strain HM-1:IMSS was obtained from the American Type Culture Collection (Rockville, MD) and cultured in TYI-S-33 media (28). Nine pathogenic and 12 nonpathogenic clinical isolates were cultured directly from stools or liver abscesses into Robinson's media as previously described (29). Three strains (SAW 760, SAW 1453, and SAW 1734) were a gift from Peter Sargeaunt (London School of Hygiene and Tropical Medicine), and five strains 
(FAT 957, FAT 967, FAT 973, FAT 1010, and FAT 1014) were a gift from T.H.F.G. Jackson (Research Institute for Diseases in a Tropical Environment, Durban, South Africa). One strain was cultured from a patient in a refugee camp in Costa Rica (REF 291). The other 12 strains ( pathogenic: SD 4, 53, 92, 135, and 136; nonpathogenic: SD 11, $107,116,130,137,143$, and 147) were isolated by the Microbiology Laboratory at the University of California Medical Center, San Diego. Strains were assigned to zymodemes by the method of Sargeaunt et al. (5).

DNA and RNA purification. DNA was isolated by a modification of the method of Huber et al. (30). Cell pellets from clinical isolates were first incubated with proteinase $\mathrm{K}(1 \mathrm{mg} / \mathrm{ml})$ for $2 \mathrm{~h}$ at $56^{\circ} \mathrm{C}$. Total RNA was isolated from $10^{7}$ to $10^{8}$ trophozoites according to the method of Chomczynski and Sacchi (31).

PCR amplification and sequencing. Degenerate oligonucleotide primers based on active site sequences conserved in all eukaryotic cysteine proteinases were used to amplify cysteine proteinases from genomic HM-1 strain DNA by the PCR under conditions previously described (27). A new 5' primer (GCC GAA TTC GCT GCT CCA GAA TCA GTT GAT TGG AGA ) based upon the amino-terminal sequence of ACP1 was used with the original 3' primer to amplify and isolate the two additional proteinase gene fragments (ACP2 and ACP3). The 5' sequence of the mature $A C P 2$ proteinase was then confirmed using a new 3' primer (AAA GGA TCC ACA TGA TCC GCA TTG TC/ GC TT).

The remaining sequence of ACP2 was obtained using an E. histolytica cDNA library in $\lambda$ gt 11 (strain H-302:NIH; a gift from Dr. Bruce Torian) (32). DNA was purified from bacteriophage plaques by bind- ing to DEAE-cellulose (DE52; Whatman Inc., Clifton, NJ). The 5' sequence was obtained by PCR using a $\lambda g t 11$ reverse sequencing primer (Promega Corp., Madison, WI) and a second primer corresponding to a seven-amino acid sequence at residues 18-25 of the mature ACP2 enzyme (5'-AGA GTC GAC TGT ATA ACA TGA TCC ACA TTG TCC TTG ATC). After PCR amplification, a 321-bp fragment that encoded the entire pro-sequence was obtained. The carboxy-terminal sequence was similarly obtained by PCR using the forward sequencing primer for $\lambda \mathrm{gt} 11$ (antisense) and a sense primer made to the same seven-amino acid sequence. Sequencing was performed by the dideoxy method with the Sequenase Kit (U.S. Biochemical Corp., Cleveland, $\mathrm{OH}$ ) or by automated dye terminator sequencing at the Biomolecular Resource Center, University of California at San Francisco, using an ABI373A instrument.

Genomic library. An E. histolytica genomic library of EcoRI*-digested DNA fragments was prepared in Lambda ZAP (Stratagene, Inc. San Diego, CA). The ACP1 probe ( $452 \mathrm{bp}$ ) was labeled by the random primer method (Bethesda Research Laboratories, Gaithersburg, MD) and used to screen $2 \times 10^{6}$ plaques. Five clones were selected after tertiary screening and sequenced.

Southern and Northern analysis. For Southern blot analysis, 5-10 $\mu \mathrm{g}$ of DNA was digested with EcoRI and subjected to electrophoresis on $0.8 \%$ GTG agarose gels (FMC Corp., Rockland, ME) and transferred to Gene Screen Plus nylon membranes (New England Nuclear Research Products, Boston, MA). Hybridizations were performed under high stringency by the method of Church and Gilbert (33) in 7\% SDS, $0.5 \mathrm{M} \mathrm{NaHPO}_{4}$, pH 7.2, $1 \mathrm{mM}$ EDTA, and $1 \%$ bovine serum albumin at $65^{\circ} \mathrm{C}$. Ethidium bromide staining of the gel and hybridiza-
ACP1

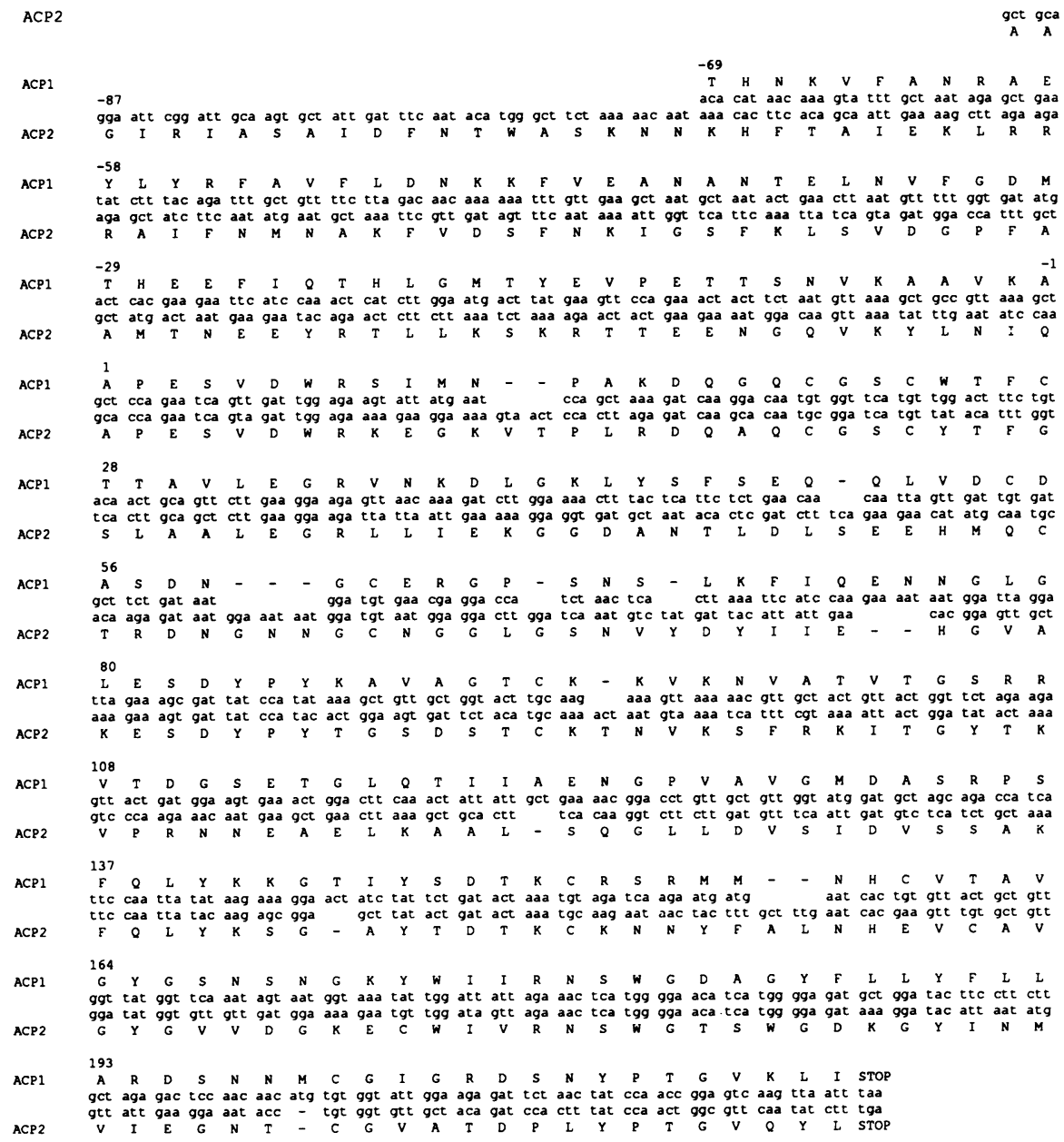

ACP1

ACP2

ACP1

ACP2

ACP1

ACP2

ACP1

ACP2

ACP1

ACP2

ACP1

ACP2

ACP1

ACP2

ACP1

ACP2

ACP1

ACP2

ACP1

ACP2

ACP2

Figure 1. Nucleic acid and predicted protein sequences of cysteine proteinase genes from E. histolytica HM-1 strain. ACP1 and ACP2 are shown. The ACP3 gene fragment was identical to a cDNA sequence (cEh-CPp) previously published (10); the amino acid sequence of ACP3 is shown in Fig. 6. Sequence data for ACP1 is from a genomic clone and includes $207 \mathrm{bp}$ of proenzyme sequence 5 ' to the amino terminus of the mature proteinase. Residue +1 is the amino terminus of mature proteinase. 


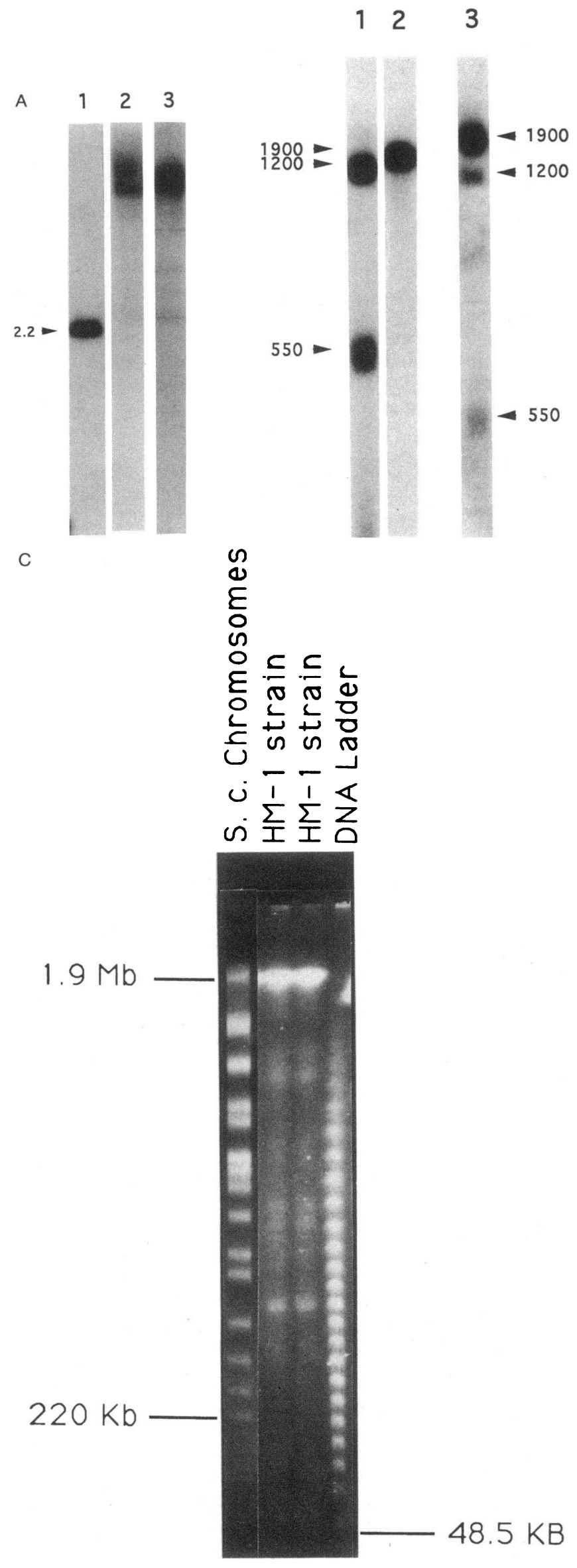

tion of the blot with ${ }^{32} \mathrm{P}$-labeled $E$. histolytica actin cDNA (34), a gift of Dr. Isaura Meza, confirmed the presence of equivalent amounts of DNA from pathogenic and nonpathogenic strains. For Northern analysis, 5-10 $\mu \mathrm{g}$ of total RNA was subjected to electrophoresis on a $1 \%$ agarose-2.2 M formaldehyde gel in 3-( $N$-morpholino)propanesulfonic acid buffer and transferred to Gene Screen Plus nylon membranes. Hybridizations were performed under identical conditions.

Ribonuclease protection assay. Antisense RNA transcripts were synthesized from Bluescript (pKS) vectors containing the ACP1 gene cut with SmaI and ACP2 cut with EcoRI to terminate transcription of the insert. $\alpha-\left[{ }^{32} \mathrm{P}\right]$ CTP-labeled transcript was synthesized with the T3 bacteriophage polymerase according to the Maxiscript kit instructions (Ambion, Inc., Austin, TX) and the DNA template was digested with RNase-free DNase. Aliquots of 5-10 $\mu \mathrm{g}$ of total RNA were added to a fourfold molar excess of labeled probe and hybridized at $42^{\circ} \mathrm{C}$ overnight using the RPAII kit (Ambion, Inc.). Unhybridized RNA was digested with RNase A, RNA hybrids were precipitated and pelleted, and the fragments were separated on an $8 \mathrm{M}$ urea, $5 \%$ acrylamide gel. The intensity of the resulting bands on autoradiographs was compared by scanning with a Quikscan (Helena Laboratories, Beaumont, TX).

Field inversion gel electrophoresis (FIGE). Trophozoites were harvested from early stationary phase cultures and washed twice by centrifugation $(10 \mathrm{~min}$ at $200 \mathrm{~g})$ in TSE buffer $(100 \mathrm{mM} \mathrm{NaCl}, 50 \mathrm{mM}$ EDTA, $20 \mathrm{mM}$ Tris base, pH 8.0). An equal volume of melted $1.2 \%$ InCert Agarose (FMC Corp.) in TSE was added to the parasite pellet. The mixture was poured into $63-\mu \mathrm{l}$ wells of a Hexa-A-Field agarose plug mold (Bethesda Research Laboratories) and allowed to gel at $4^{\circ} \mathrm{C}$. The agarose blocks were transferred to a tube containing $10 \mathrm{ml}$ of TSE plus $1 \% N$-lauroylsarcosine, $1 \%$ Nonidet $\mathrm{P}-40$, and incubated for $3 \mathrm{~h}$ with gentle agitation at $4^{\circ} \mathrm{C}$. The buffer was then replaced with fresh TSE, $1 \% N$-lauroylsarcosine (TSE-Sarkosyl) and stored at $4^{\circ} \mathrm{C}$ for a minimum of $18 \mathrm{~h} .5 \mathrm{~h}$ before use the agarose plugs were transferred to a new tube containing TSE-Sarkosyl with $2 \mathrm{mg} / \mathrm{ml}$ Proteinase $\mathrm{K}$ and incubated at $45^{\circ} \mathrm{C}$

FIGE was performed in a horizontal electrophoresis unit (model HE 100 SuperSub Hoefer, Scientific Instruments, San Francisco, CA) connected to a PC 750 pulse controller (model PC 750; Hoefer Scientific Instruments). The agarose plugs were loaded into wells of a $1.2 \%$ agarose gel (Seakem agarose; FMC Corp.) made with 1.0 $\times$ TBE buffer ( $89 \mathrm{mM}$ Tris base, $89 \mathrm{mM}$ boric acid, $2 \mathrm{mM}$ EDTA, pH 8.0). DNA molecules were separated using two cycles at a constant voltage of 125 $\mathrm{V}$ at $8^{\circ} \mathrm{C}$ in $1 \times \mathrm{TBE}$ buffer. The first cycle was run with a beginning forward pulse of $2.4 \mathrm{~s}$, a reverse pulse of 0.8 with a 1.6 ramp value for 22-24 $\mathrm{h}$. The second cycle lasted 20-24 $\mathrm{h}$ with an initial forward pulse of $3.6 \mathrm{~s}$ and 1.2 reverse pulse with a $1.6 \mathrm{ramp}$ value. Lambda DNA ladder and Saccharomyces cerevisiae chromosomal DNA (FMC Corp.) were included to estimate the molecular size of the $E$. histolytica chromosomes. The DNA was depurinated with $0.2 \mathrm{~N} \mathrm{HCl}$ for $10 \mathrm{~min}$ and denatured with $0.5 \mathrm{~N} \mathrm{NaOH}$ for 45 min before it was transferred to nylon membranes. Hybridizations were performed in $30 \%$ formamide,

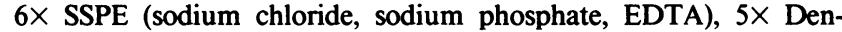
hardt's, $0.2 \% \mathrm{SDS}$, and $100 \mu \mathrm{g} / \mathrm{ml}$ transfer RNA (tRNA) at $45^{\circ} \mathrm{C}$ overnight. The filters were washed as described in Sambrook et al. (35) at a final temperature of $68^{\circ} \mathrm{C}$ for $30 \mathrm{~min}$.

Proteinase purification and peptide sequencing. HM-1 trophozoites were washed and suspended at a concentration of $10^{7} / \mathrm{ml}$ in PBS and

Figure 2. $(A)$ Southern blot of ACP1, ACP2, and ACP3 with HM-1 strain DNA. Southern hybridization of EcoRI-digested DNA from E. histolytica axenic strain HM-1 with a probe corresponding to the ACP1 gene (lane 1), ACP2 gene (lane 2), and ACP3 gene (lane 3). $(B)$ Southern blot after FIGE of DNA from HM-1 strain hybridized with ACP1 and ACP2 genes. Lane 1, ACP1; lane 2, ACP2 hybridized to same blot; lane 3 , both probes simultaneously hybridized to second blot. ACP3 gave identical pattern to ACP2 (not shown). Note unique location of ACP1 gene copy on < 550-kb "chromosome." $(C)$ Ethidium bromide-stained FIGE gel used for Southern blot transfer in $B$. 


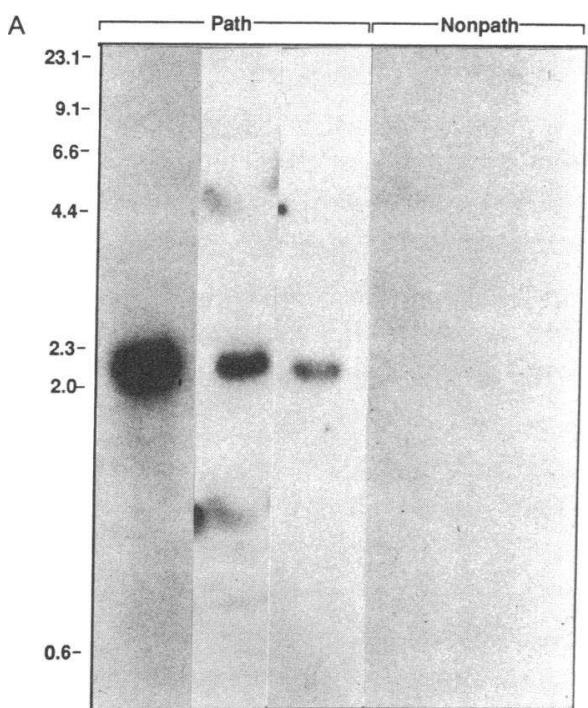

B
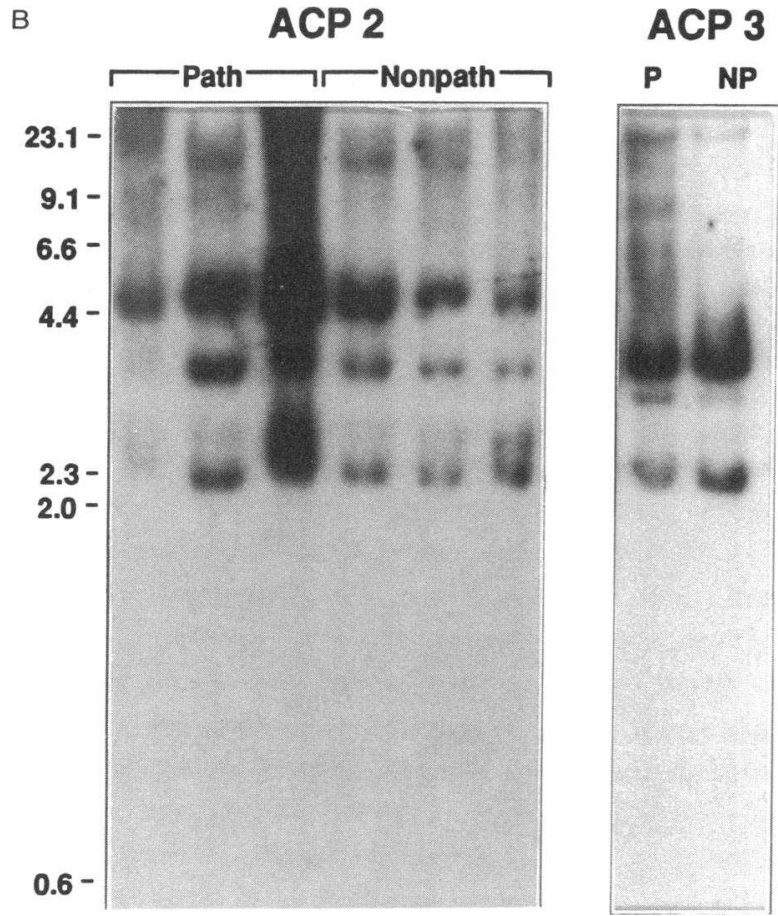

Figure 3. (A) Southern blot of ACP1 cysteine proteinase gene with DNA of clinical isolates. Southern hybridization of EcoRI-digested DNA from pathogenic (Path) and nonpathogenic (Nonpath) clinical isolates with ACP1 at $65^{\circ} \mathrm{C}$. Examples of three of nine pathogenic and three of nine nonpathogenic isolates are shown. $(B)$ Southern blot of ACP2 and ACP3 cysteine proteinase gene with DNA of clinical isolates. Southern hybridization of EcoRI-digested DNA with ACP2 (three of six pathogenic and three of five nonpathogenic strains shown) and ACP3 (one of three pathogenic and one of three nonpathogenic strains shown) at $55^{\circ} \mathrm{C}$.

incubated for $3 \mathrm{~h}$ at $37^{\circ} \mathrm{C}$. Cysteine proteinase activity was identified and the enzyme purified from the supernatant by fast protein liquid chromatography as previously described (17). Both the high molecular mass $(56 \mathrm{kD})$ and low molecular mass $(27 \mathrm{kD})$ forms of the proteinase were purified. The purified proteinase was subjected to electrophoresis by SDS-PAGE on a $10 \%$ gel and transferred to a polyvinylidenedifluor- ide membrane (Immobilon; Millipore Corp., Bedford, MA) by the method of Matsudaira (36). Peptide sequencing of the amino terminus was performed at the Biomolecular Resource Center at University of California at San Francisco, using a gas phase sequencer (Applied Biosystems Inc., Foster City, CA).

Monolayer assay for cytopathic effect. Trophozoites were purified from xenic media as previously described (16) and resuspended in PBS containing $20 \mathrm{mM}$ cysteine, $0.15 \mathrm{mM} \mathrm{CaCl}_{2}$, and $0.5 \mathrm{mM} \mathrm{MgCl}_{2}$ at a concentration of $10^{7} / \mathrm{ml}$. After incubation for $3 \mathrm{~h}$ at $37^{\circ} \mathrm{C}$, the supernatants were separated and passed through a $0.2-\mu \mathrm{M}$ filter to remove remaining bacteria from the medium. This procedure did not affect the proteinase activity but was necessary to remove any residual bacterial flora, which is different for each clinical isolate. Proteinase activity was quantified by the cleavage of a synthetic peptide substrate, Z-Arg-ArgAMC (benzyloxycarbonyl-arginine-arginine-4-amino-7-methylcoumarin ) (Enzyme Systems Products, Livermore, CA), as previously described (17), and recorded as the initial velocity of cleavage of the fluorescent 4-amino-7-methylcoumarin / $10 \mu \mathrm{l}$. Proteinase activity was inhibited by preincubating with Z-Phe-Arg- $\mathrm{CH}_{2} \mathrm{~F}$, an irreversible cysteine proteinase inhibitor $\left(10 \mu \mathrm{M}\right.$ for $30 \mathrm{~min}$ at $\left.37^{\circ} \mathrm{C}\right)$, which has no effect on the viability of the monolayer (Enzyme Systems Products). 24-well culture plates were seeded with $2 \times 10^{5}$ cells from a foreskin epithelial cell line (HFS 1 ) and incubated overnight in DME with $10 \%$ fetal calf serum in $\mathrm{CO}_{2}$. The medium supplemented with serum was removed and the monolayer washed twice with MEM without sera. Amebic supernatants $(100 \mu \mathrm{l})$ were added in triplicate to $400 \mu \mathrm{l}$ of MEM and incubated for $3 \mathrm{~h}$ at $37^{\circ} \mathrm{C}$ with $\mathrm{CO}_{2}$. Detached cells were removed by washing twice with PBS. The remaining cells were fixed (4\% Formalin) and quantified by staining with methylene blue dye ( $0.1 \%$ in $0.1 \mathrm{M}$ borate, $\mathrm{pH} 8.7)$ and measuring the extracted absorbance at $660 \mathrm{nM}(22)$. Cytopathic effect $(\mathrm{CPE})^{1}$ was calculated as the absorbance of control wells (MEM alone) minus the absorbance of sample wells divided by control $\times 100 \%$. To control for variations between different experiments, the values were standardized against the CPE caused by strain HM-1, which was taken as 1.00 (relative $\mathrm{CPE}$ ).

\section{Results}

To isolate the cysteine proteinase genes of $E$. histolytica, we amplified cysteine proteinase gene fragments by PCR using primers based on conserved structural motifs identified in the eukaryotic cysteine proteinase family (27). A 450-bp fragment was initially amplified from DNA isolated from the pathogenic axenic strain HM-1, as previously reported (27). The 450-bp fragment was subsequently used to isolate a genomic clone (ACP1) containing the entire coding region of the mature proteinase (Fig. 1). A second set of primers based on the amino terminus of this gene and the region around the active site asparagine was then used to amplify two 550-bp genomic fragments of the second and third cysteine proteinase genes (ACP2 and ACP3) (Fig. 1). The 5' end of ACP2, representing the amino terminus of the mature proteinase, was then confirmed by sequence from genomic DNA using a 3' to 5' primer based on adjacent downstream sequence (see Methods). The $5^{\prime}$ pro sequence and the carboxy-terminal sequence of ACP2 were obtained by PCR from DNA purified from a cDNA library (see Methods). The sequence of the ACP3 fragment was found to be identical to the sequence of a cDNA, cEh-CPp, previously published by Tannich et al. (10).

To confirm that these genes encoded $E$. histolytica protein-

1. Abbreviations used in this paper: CPE, cytopathic effect; FIGE, field inversion gel electrophoresis. 
ases and were expressed in the HM-1 strain, we purified proteinase from the culture supernatant of this strain. Microsequencing of the first eight amino acids of the amino terminus of the purified $27-\mathrm{kD}$ enzyme revealed heterogeneity at positions 3 and 4 in an approximately equimolar ratio (2.1:1.8), A-P-E/K-S/A-V-D-W-R. One sequence (APES . .) was identical to that predicted from ACP1 and ACP2 and also identical in seven out of eight residues with the amino-terminal sequence of a cysteine proteinase (called "histolysin") purified by Luaces and Barrett (18) from HM-1 trophozoites. The second sequence (APKA . . .) was identical to the first eight residues of the cEh-CPp proteinase predicted from a cDNA clone isolated from HM-1 amebae by Tannich et al. (10). The nucleotide sequence of $\mathrm{cEh}-\mathrm{CPp}$ is identical to ACP3.

Southern blot analysis showed that the ACP1 gene fragment hybridized with a single restriction fragment in EcoRI $(2.2 \mathrm{~kb})$ - (Fig. $2 A)$ or Bgl II ( $3 \mathrm{~kb})$ - (not shown) digested HM-1 genomic DNA whereas ACP2 and ACP3 each hybridized to two larger ( 10 and $12 \mathrm{~kb}$, respectively) EcoRI fragments (Fig. $2 A$ ). Southern blot analysis after FIGE of HM-1 strain (Fig. $2 B$ ) showed that the ACP1 gene fragment hybridized with two DNA bands of a relative size of $\sim 1 \mathrm{Mb}$ and $550 \mathrm{~kb}$. In contrast, the ACP2 and ACP3 gene fragments hybridized with a single DNA band of relative size $1.9 \mathrm{Mb}$. FIGE-derived Southern blots hybridized with mixtures of ACP1 and ACP2 or ACP3 gene fragments (Fig. $2 B$, lane 3 ) showed three hybridization sites: $1.9 \mathrm{Mb}$ corresponding to ACP2/ACP3 genes, and 1 $\mathrm{Mb}$ and $550 \mathrm{~kb}$ corresponding to the $\mathrm{ACP} 1$ gene as described above. These data suggested there was a distinct chromosomal location for the ACP1 gene versus ACP2 and ACP3. The detection of two sites of hybridization of the ACP1 probe on FIGE suggested more than one gene copy was present. The presence of multiple gene copies was also supported by repeating Southern blot analysis under conditions of varying EcoRI digestion $(0.1,0.5,2,4$, and $8 U)$. Six hybridization bands were detected ranging in six regular increments from 2.2 to $10 \mathrm{~kb}$, suggesting multiple gene copies are present, at least six of which may be in tandem. This pattern was reminiscent of the multiple tandem copies of the cysteine protease gene of Trypanosoma cruzi (37).

To determine whether the presence of any of these genes was correlated with amebic virulence, DNA was extracted from nine pathogenic and nine nonpathogenic clinical isolates classified by their zymodeme patterns and the clinical syndrome of the patients (5). In Southern blot analysis of EcoRI-digested DNA from all nine pathogenic isolates, ACP1 hybridized to a 2.1-2.3-kb fragment, similar to that seen in the digest of HM-1 DNA. It did not hybridize to any DNA fragment from any of the nine nonpathogenic isolates (Fig. $3 A$ ). A portion of the cysteine proteinase gene from one pathogenic clinical isolate (SAW 1453) was amplified by PCR. The 450-bp amplified sequence from this isolate was identical to that of the HM-1 axenic strain (ACP1) shown in Fig. 1. However, there was slight but detectable variation in size $(2.1-2.3 \mathrm{~kb})$ or intensity of the EcoRI fragment in DNA from other pathogenic isolates, suggesting the presence of some sequence heterogeneity at this locus among different isolates.

In contrast, ACP2 hybridized to 2.2-, 4.0-, and 5.5-kb fragments and ACP3 hybridized to 2.2-, 2.9-, and 3.6-kb fragments in EcoRI-digested DNA from six pathogenic and five nonpathogenic clinical isolates (Fig. $3 \mathrm{~B}$ ). Because complete genomic clones of ACP2 and ACP3 were not available, it is difficult to
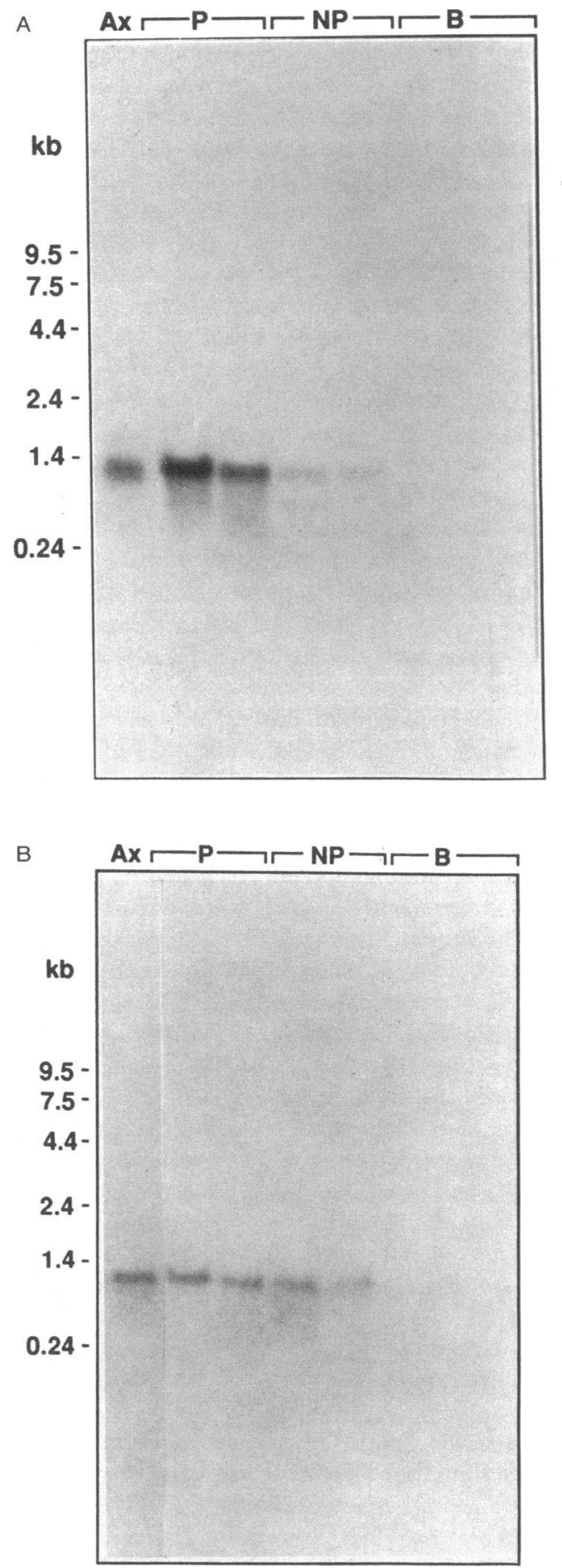

Figure 4. $(A)$ Northern blot with ACP1. Northern blot of pathogenic $(P)$, nonpathogenic $(N P)$, and bacteria $(B)$ RNA hybridized with ACP1 gene probe. Examples of three of five pathogenic and two of five nonpathogenic isolates are shown. (B) Northern blot with ACP2. Same blot as $A$ with ACP2 gene as probe. ( $C$ ) RNase protection assay. Total RNA from one axenic (HM-1;Ax), three pathogenic (Path), and four nonpathogenic (Nonpath) strains was hybridized with antisense RNA transcripts from ACP1 and ACP2.

assign specific map positions to the fragments in Fig. $3 \mathrm{~B}$. It is possible some may be the result of partial digestion by the restriction enzyme. None of the ameba gene probes hybridized to 

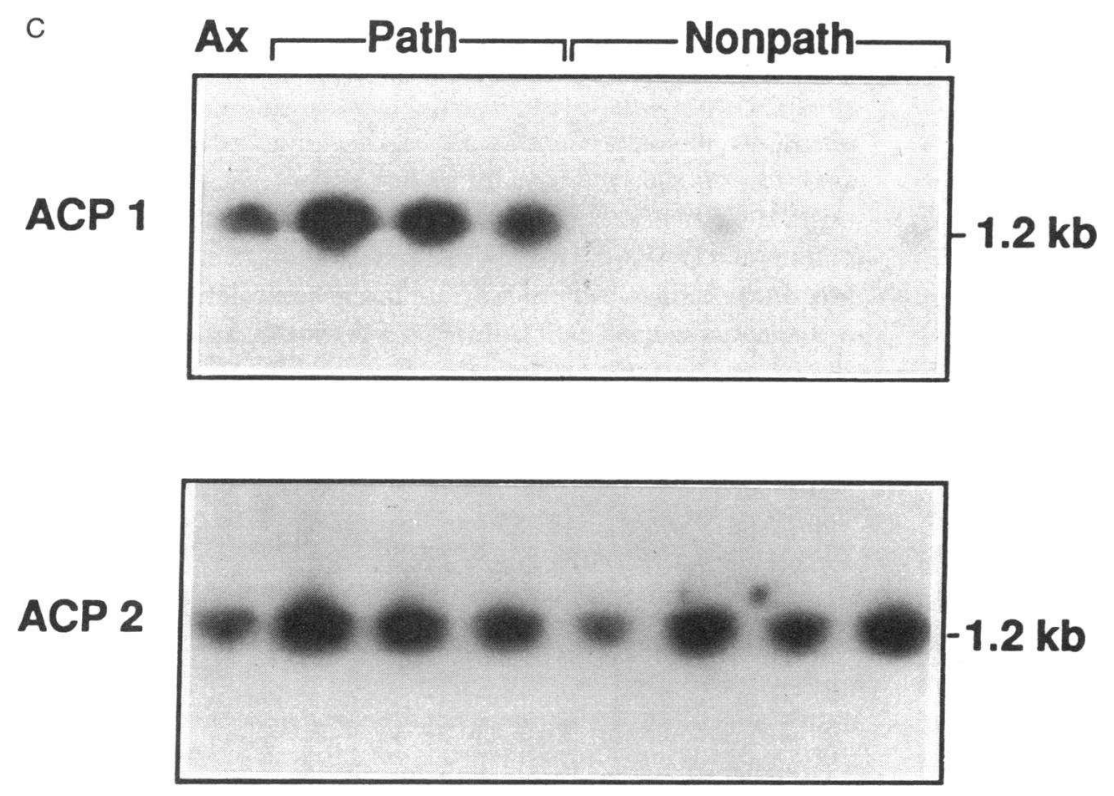

Figure 4. (Continued)

DNA from the bacteria in the cultures of clinical isolates. Northern blots probed with ACP1 revealed a strong signal at $1.2 \mathrm{~kb}$ with RNA from HM-1 and five of five pathogenic strains, but only a faint band in five of five nonpathogenic strains (Fig. $4 \mathrm{~A}$ ). When the same blot was hybridized with the ACP2 probe, a band of equivalent intensity and identical molecular weight was observed with all strains. The ACP3 probe also hybridized to a band of identical size in all three pathogenic and four nonpathogenic RNA samples tested (not shown). These Northern blots suggested that ACP2 and ACP3 were expressed in all isolates whereas ACP1 was expressed only in pathogenic isolates but crosshybridized weakly with the other genes (faint bands in nonpathogenic lanes in Fig. $4 \mathrm{~A}$ ). To confirm this result with a more sensitive measure of potentially low abundance mRNAs, ribonuclease protection assays were performed using antisense RNA transcripts synthesized from ACP1 and ACP2. A 1.2-kb band was detected in all isolates with the ACP2 probe whereas the ACP1 probe hybridized strongly only with transcripts from the pathogenic isolates (Fig. $4 C$ ).

To directly correlate the presence of the ACP1 gene in pathogenic amebae with enhanced proteinase activity and a quantitative assay of virulence, the total cysteine proteinase activity of amebic supernatants was determined and correlated in the same ameba isolates with the cytopathic effect on a fibroblast cell monolayer. The proteinase activity (initial velocity/ $10 \mu \mathrm{l}$ ) of five pathogenic strains containing ACP1 was significantly greater than that of four nonpathogenic strains lacking it $(P<0.03)$ (Fig. 5). The relative CPE (corrected to that of HM-1 as 1.00 ) by pathogenic strains was also significantly greater $(P<0.001)$ and was completely inhibited, as demonstrated previously (22), by preincubation with $100 \mu \mathrm{M} \mathrm{Z-Phe-}$ Arg- $\mathrm{CH}_{2} \mathrm{~F}$, an irreversible and specific cysteine proteinase inhibitor. Furthermore, the enhanced proteinase activity correlated with elevated cysteine proteinase mRNA in the pathogenic versus nonpathogenic isolates (Fig. 5). In summary, Fig. 5 shows that the presence of an additional cysteine proteinase gene (ACP1) in pathogenic isolates correlates with increased proteinase mRNA, increased proteinase activity, and increased CPE that is inhibited by Z-Phe-Arg- $\mathrm{CH}_{2} \mathrm{~F}$, a cysteine proteinase inhibitor.

The coding sequence of ACP1 predicted an amino acid sequence with only $35-45 \%$ identity to the other two genes. In contrast, ACP2 and ACP3 were $85 \%$ identical to each other in

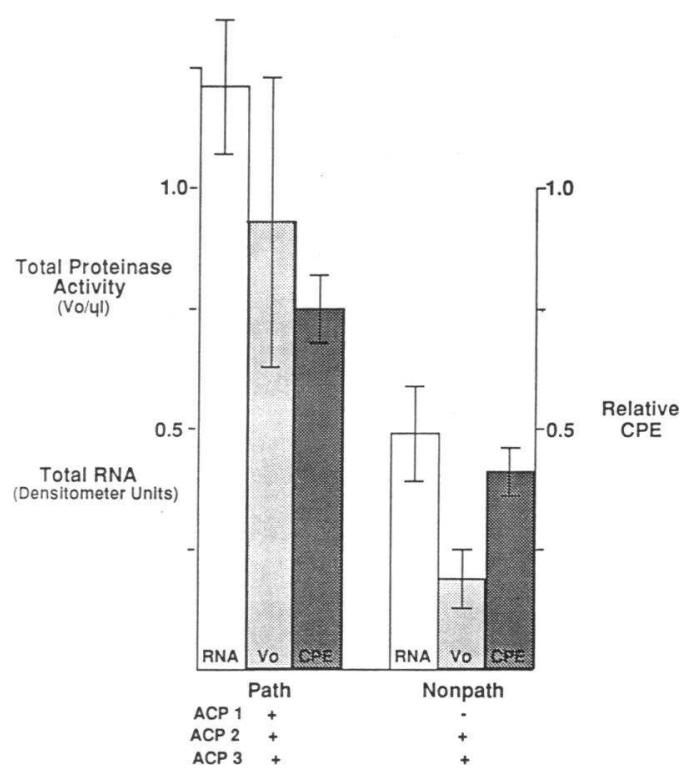

Figure 5. Proteinase activity (measured as initial velocity, $\mathrm{Vo} / 10 \mathrm{ml}$ ) of supernatants of clinical isolates $\left(10^{7}\right.$ amebae $\left./ \mathrm{ml}\right)$ compared with the relative CPE (measured as percent of monolayer destruction/ percent destruction by axenic strain HM-1) and total cysteine proteinase mRNA. Proteinase activity is the mean \pm SEM for 13 measurements of five pathogenic strains and 18 measurements of four nonpathogenic strains. CPE is mean \pm SEM for five pathogenic and four nonpathogenic isolates. Sum of mRNA for ACP1 and ACP3 assayed by densitometer scan of signals from RNase protection assays of three pathogenic and four nonpathogenic isolates. + or - indicates presence or absence of each gene by Southern blot analysis (see Fig. 2). 
predicted amino acid sequence and 90 and $100 \%$ identical at the nucleic acid level to the two corresponding genes (cEhCPnp and cEh-CPp) isolated previously by Tannich et al. (10). All three genes were also homologous to the major excreted protein of transformed fibroblasts (26) as well as other members of the cysteine proteinase family of enzymes (Fig. 6). Specifically, all three amino acid residues of the catalytic triad of cysteine proteinases (cysteine, histidine, and asparagine) were present, and structural motifs flanking these residues were highly conserved (Fig. 6).

\section{Discussion}

The potential multifactorial roles of cysteine proteinases in invasion of pathogenic amebae are well documented (16-22). They include degradation of host extracellular matrix and mucoproteins, dislodgment of epithelial cells and degradation of epithelial basement membrane, and possibly recruitment of inflammatory cells to sites of ameba invasion by activation of complement.

We have now shown that the enhanced expression and release of cysteine proteinase activity by virulent laboratory strains $(17,20)$ and pathogenic clinical isolates (16) correlates with the presence of a unique cysteine proteinase gene (ACP1), which was not detected in Southern blots of DNA of nonpathogenic amebae. Tannich et al. (10) also identified restriction fragment-length polymorphisms between pathogenic and nonpathogenic strains by hybridization with two other cysteine proteinase genes. One of these genes (cEh-CPnp) may correspond to ACP2 and the other (cEh-CPp) is identical to ACP3. However, our examination of a larger set of clinical isolates suggests that neither of these latter two closely related genes is unique to nonpathogenic or pathogenic amebae (Fig. 2). We speculate that ACP2 and ACP3 arose from copies of the same gene and remain closely linked on one chromosome. Their presence in both pathogenic and nonpathogenic isolates of $E$. histolytica suggests they may play a role in basic metabolism of amebae, most likely intracellular protein degradation.

$\mathrm{ACP} 1$ is quite divergent in sequence from $\mathrm{ACP} 2$ and $\mathrm{ACP} 3$, and copies of the ACP1 gene are present on different chromosome-sized DNA fragments than ACP2 and ACP3 (Fig. $2 \mathrm{~B}$ ). Nevertheless, the data from both studies presented here together with those reported by Tannich et al. (10) are consistent with the presence of an additional cysteine proteinase gene in pathogenic strains, resulting in increased cysteine proteinase mRNA and consequently higher levels of extracellular proteolytic activity. Our observation that amino-terminal sequencing of the $E$. histolytica cysteine proteinase yields more than one signal (APE $[\mathrm{S}] \mathrm{K}[\mathrm{A}]$. . ) also supports the hypothesis that the enhanced production and release of cysteine proteinases by virulent $E$. histolytica is due to the presence and expression of multiple genes. Although our Southern blot analysis (Fig. $3 \mathrm{~A}$ ) suggested that the ACP1 gene was unique to pathogenic isolates, Orozco (38) has offered an alternative explanation for these results. She speculates that gene amplification may lead to enhanced expression of virulence factors in pathogenic amebae. We cannot exclude the possibility that our hybridization conditions did not identify a single copy of ACP1 in nonpathogenic isolates and that the gene is highly amplified in pathogenic DNA, leading to enhanced cysteine proteinase expression. In fact, the results of varying EcoRI digestion conditions (0.1-8 U of enzyme) suggested that multiple tandem copies of ACP 1 were present. FIGE also suggested that there were at least two distinct chromosome locations for ACP1 gene copies (Fig. $2 B$ ). In either case, we speculate that in pathogenic isolates the expression of the ACP1 gene(s) in addition to expression of $\mathrm{ACP} 2$ and $\mathrm{ACP} 3$ genes results in extracellular proteinase activity exceeding a critical threshold, which, coupled with other virulence factors (11-18), may lead to tissue lysis, invasion of the bowel wall by trophozoites, and disseminated infection.

There are striking parallels in the release of cathepsin $\mathrm{L}$ and $B$ by invasive cancer cells or activated macrophages and cys-

\begin{tabular}{|c|c|c|c|c|c|}
\hline ACP1 & APESVDWR & SIMN & PAKDQGQCGSCWTF & CTTAVLEGRVNKDLGKLYSF & SEQQLVDCDASDN \\
\hline ACP2 2 & APESVDWR & KEGKVT & PIRDQAQCGSCYTF & GSLAALEGRLLIEKGDANT & LEEHMVQCTRDNGNN \\
\hline ACP 3 & APKAVDWR & KKGKVT & PIRDQGNCGSCYTF & GSIAALEGRLLIEKGGDSETLDL & SEEHMVQCTREDGNN \\
\hline MEP & APRSVDWR & EKGYVT & PVKNQGQCGSCWAF & SATGALEGQMFRKTGRLISL & SEQNLVDCSGPQGNE \\
\hline CB & LPASFDAR & EQWPQCPTIKE & IRDQGQSCGSCWAF & GAVEAISDRICHIHTNVSVEV & SAEDLLDCCGIQCGD \\
\hline $\mathrm{P}$ & $\begin{array}{l}\text { IPEYVDWR } \\
\text { pr1mer } 3\end{array}$ & QKGAVT & $\begin{array}{c}\text { PVKNQGSCGSCWAF } \\
\text { primeI } 1\end{array}$ & SAVVTIEGIIKIRTGNLNQY & SEQELLDCDRRSY \\
\hline
\end{tabular}

ACP1 GCERGHP SNSLKFIQENNGLGLESDYPYKAVAGTCKKVKNVATVTGSRRVTD ACP2 GCNGGLG SNVYDYIIE NGVAKESDYPYTGSDSTCKTNVKSFRKITGYTKVP ACP 3 GCNGGLG SNVYNYIME NGIAKESDYPYTGSDSTCRSDVKAFAKIKSYNRVA MEP GCNGGLM DYAFQYVQD NGGLDSEESYPYEATEESCKYNPKYSVANDTGFDIPKQE $\begin{array}{lll}\text { CB } & \text { GCNGGYP AEAWNFWTR KGLVSGGYRSHVGCRPYSIPPCEHHVNGSRPPCTGEGDT } \\ \mathrm{P} & \text { GCNGGYP WSALOLVAO YGIHYRNTPYYEGVORYCRSREKGPYAAKTDGVROVOPY }\end{array}$ 66
ACP1 GSETGLQTIIAENGPVAVGMDASRPSFQLYK KGTIYSDTKCRSR MMN H CVTAV ACP2 RNNEVELKAALSQGLLDVSIDVSSAKFQLYK GGAYTDTKCKNNYEALN H QVCAV ACP 3 RNNEVELKAAISQGLVDVSIDASSVQFQLYK SGAYTDTQCKNNYFALN H EVCAV MEP KALMKAVATVGPISVAID AGHESFLFYK EGIYFEPCDSSE DMD H GVLVV

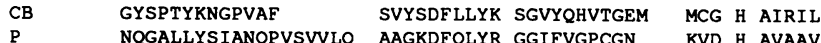
NQGALLYSIANQPVSVVLQ AAGKDFQLYR GGIFVGPCGN KVD H AVAAV 125 159

$\begin{array}{llcll}\text { ACP1 } & \text { GYG SNSNG } & \text { KYWIVKNSWGTSWGDAGYFL } & \text { LARDSNNM } & \text { CGIGRDDSNYPTGVKLI } \\ \text { ACP2 } & \text { GYG VVDGKEC } & \text { WVVRNSWGTSWGDKGINMVIEGNT } & \text { CGVATDPLYPTCVQYL } \\ \text { ACP 3 } & \text { GYG VADGKEC } & \text { WIVRNSWGTGWGEKGYINMVIEGNT } & \text { CGVATDPLYPTGVEYL } \\ \text { MEP } & \text { GYG FESTESDNN } & \text { KYWLVKNSWGEFWGMGGYIK IAKDRDNH } & \text { CGLATAASYPVVN } \\ \text { CB } & \text { GWG VENGTP } & \text { YWLVANSWNTDWGNGFFK } & \text { ILRGQDH } & \text { CGIESEVVAGIPRTD } \\ \text { P } & \text { GYN PG } & \text { YILVANSWGTGWGENGYIRIKRGTGNSYGV } & \text { CGLYTSSFYPVKN } \\ & & & \end{array}$

Figure 6. Alignment of predicted sequences of the cysteine proteinases of $E$. histolytica (ACP1, ACP2, and ACP3) to the secreted cysteine proteinase (cathepsin L) of transformed fibroblasts ( $M E P$ ), human cathepsin $\mathrm{B}(C B)$, and papain $(P)$. Active site residues marked by asterisk. Conserved regions used for PCR primers are indicated. Sequence of ACP3 determined from this study is from primer ${ }^{1}$ to primer $^{2}$ site; the remaining sequence shown is that published for the identical gene cEh-CPp (10). 
teine proteinase release by pathogenic amebae. In each case, cysteine proteinases are found both in intracellular digestive organelles as well as released extracellularly in multiple molecular forms, including active or activatable proenzymes $(17,24$ 26 ). Like the targeting of cysteine proteinases to lysosomes or endosomes in mammalian cells, the cysteine proteinases of both pathogenic and nonpathogenic strains of $E$. histolytica appear to be targeted at least in part to endosome-like cytoplasmic vacuoles where endocytosed bacteria and cells are degraded (39). Default secretion due to alterations in mannose6-phosphate containing signal moieties or transcriptional overexpression of specific proteinase genes are two mechanisms by which transformed mammalian cells are thought to release lysosomal cysteine proteinases into the extracellular milieu (26). In amebae there is a correlation between elevated rates of phagocytosis and virulence (40), and phagocytosis-deficient mutants release less extracellular cysteine proteinase (22). The adaptive advantage for the pathogenic amebae of an additional cysteine proteinase gene and, consequently, higher levels of extracellular cysteine proteinase may therefore be related to enhanced phagocytosis and/or extracellular digestion of bacteria and cells.

At this time we cannot exclude the possibility that the differences in the coding sequence of the three cysteine proteinase genes of $E$. histolytica might reflect distinct transport or biochemical properties. However, at least the specificity for synthetic peptide substrates among the three gene products appears to be identical (17-20) and, unlike their mammalian counterparts, none of the ameba cysteine proteinases contain asparagine-linked carbohydrate addition sites for mannose6-phosphate lysosome targeting signals (Fig. 6) (10).

All previous studies of virulence have used axenized pathogenic strains that have become attenuated to varying degrees during cultivation. A direct comparison to nonpathogenic strains has not been possible because these strains have never been axenized. On the basis of the observations reported here, we can now confirm that there are quantitative differences in CPE between authentic pathogenic and nonpathogenic clinical isolates, which in turn correlate with the presence of the ACP1 gene in pathogenic strains and enhanced proteinase release (Fig. 5). Noteworthy, however, is the observation that CPE is not totally absent in nonpathogenic isolates and therefore cannot be used alone as an assay of pathogenicity, as was suggested by its historical use with axenic strains. We also confirm previous studies (22) that CPE is inhibited by a specific inhibitor of cysteine proteinases.

It is likely that host immune status, nutritional status, and associated intestinal bacteria influence susceptibility to colonization and invasion by $E$. histolytica. However, our identification of a cysteine proteinase gene that is specific to pathogenic strains and correlates with increased extracellular proteinase activity argues strongly that the potential for pathogenicity is an intrinsic property of the organism.

\section{Acknowledgments}

This work was funded in part by the Lucille P. Markey Foundation, National Institutes of Health grants AI-28035 (S. Reed) and DK35108 (S. Reed), and the Department of Veterans Affairs (J.H. McKerrow). S. Reed is a Lucille P. Markey Scholar. J. Bouvier was a Swiss National Science Foundation Fellow.

\section{References}

1. Walsh, J. A. 1988. Prevalence of Entamoeba histolytica infection. In Amebiasis. Human Infection by Entamoeba histolytica. J. I. Ravdin, editor. John Wiley and Sons, New York. 93-105.

2. Brumpt, E. 1925. Etude sommaire de l'Entamoeba dispar n. sp. amibe a kystes quadrinuclées, parasite de l'homme. Bull. Acad. Natl. Med. (Paris). 94:942-952.

3. Mirelman, D., R. Bracha, A. Wexler, and A. Chayen. 1986. Changes in isoenzyme patterns of a cloned culture of nonpathogenic Entamoeba histolytica during axenization. Infect. Immun. 54:827-832.

4. Sargeaunt, P. G. 1987. The reliability of Entamoeba histolytica zymodemes in clinical diagnosis. Parasitol. Today. 3:40-43.

5. Sargeaunt, P. G., J. E. Williams, and J. D. Greene. 1978. The differentiation of invasive and noninvasive Entamoeba histolytica by isoenzyme electrophoresis. Trans. R. Soc. Trop. Med. Hyg. 72:519-521.

6. Tannich, E., R. D. Horstmann, J. Knobloch, and H. H. Arnold. 1989. Genomic DNA differences between pathogenic and nonpathogenic Entamoeba histolytica. Proc. Natl. Acad. Sci. USA. 86:5118-5122.

7. Garfinkel, L. I., M. Giladi, M. Huber, C. Gitler, D. Mirelman, M. Revel, and S. Rozenblatt. 1989. DNA probes specific for Entamoeba histolytica possessing pathogenic and nonpathogenic zymodemes. Infect. Immun. 57:926-931.

8. Que, X., and S. L. Reed. 1991. Nucleotide sequence of a small subunit ribosomal RNA (16s-like rRNA) gene from Entamoeba histolytica: differentiation of pathogenic from nonpathogenic isolates. Nucl. Acids Res. 19:5438.

9. Edman, U., M. A. Meraz, S. Rausser, N. Agabian, and I. Meza. 1990. Characterization of an immuno-dominant variable surface antigen from pathogenic and nonpathogenic Entamoeba histolytica. J. Exp. Med. 172:879-888.

10. Tannich, E., H. Scholze, R. Nickel, and R. D. Horstmann. 1991. Homologous cysteine proteinases of pathogenic and nonpathogenic Entamoeba histolytica. J. Biol. Chem. 266:4798-4803.

11. Ravdin, J. I. 1986. Pathogenesis of disease caused by Entamoeba histolytica: studies of adherence, secreted toxins, and contact-dependent cytolysis. Rev. Infect. Dis. 8:247-260.

12. Petri, W. A., R. D. Smith, P. H. Schlesinger, C. F. Murphy, and J. I. Ravdin. 1987. Isolation of the galactose-binding lectin that mediates the in vitro adherence of Entamoeba histolytica. J. Clin. Invest. 80:1238-1244.

13. Gitler, C., E. Calef, and I. Rosenberg. 1984. Cytopathogenicity of Entamoeba histolytica. Philos. Trans. R. Soc. Lond. Biol. Sci. B307:73-85.

14. Young, J. D., T. M. Young, L. P. Lu, J. C. Unkeless, and Z. A. Cohn. 1982. Characterization of a membrane pore-forming protein from Entamoeba histolytica. J. Exp. Med. 156:1677-1690.

15. Leippe, M., E. Sebastian, O. L. Schoenberger, R. D. Horstmann, and H. J. Müller-Eberhard. 1991. Pore-forming peptide of pathogenic Entamoeba histolytica. Proc. Natl. Acad. Sci. USA. 88:7659-7663.

16. Reed, S. L., W. E. Keene, and J. H. McKerrow. 1989. Thiol proteinase expression correlates with pathogenicity of Entamoeba histolytica. J. Clin. Microbiol. 27:2772-2777.

17. Keene, W. E., M. G. Pettit, S. Allen, and J. H. McKerrow. 1986. The major neutral proteinase of Entamoeba histolytica. J. Exp. Med. 163:536-549.

18. Luaces, A. L., and A. J. Barrett. 1988. Affinity purification and biochemical characterization of Histolysin, the major cysteine proteinase of Entamoeba histolytica. Biochem. J. 250:903-909.

19. Scholze, H., and E. Werries. 1986. Cysteine proteinase of Entamoeba histolytica. I. Partial purification and action on different enzymes. Mol. Biochem. Parasitol. 18:103-112.

20. Lushbaugh, W. B. 1988. Proteinases of Entamoeba histolytica. In Amebiasis: Human Infection by Entamoeba histolytica. J. I. Ravdin, editor. John Wiley and Sons, New York. 219-231.

21. Reed, S. L., W. E. Keene, J. H. McKerrow, and I. Gigli. 1989. Cleavage of C3 by a neutral cysteine proteinase of Entamoeba histolytica. J. Immunol. 143:189-195.

22. Keene, W. E., M. E. Hidalgo, E. Orozco, and J. H. McKerrow. 1990. Entamoeba histolytica: correlation of the cytopathic effect of virulent trophozoites with secretion of a cysteine proteinase. Exp. Parasitol. 71:199-206.

23. Barrett, A. J., and H. Kirschke. 1981. Cathepsin B, Cathepsin H, and Cathepsin L. Methods Enzymol. 80:535-561.

24. Sloane, B. F., J. R. Dunn, and K. V. Honn. 1981. Lysosomal Cathepsin B: correlation with metastatic potential. Science (Wash. DC). 212:1151-1153.

25. Mort, J. S., M. Leduc, and A. D. Recklies. 1981. A latent thiol proteinase from ascitic fluid of patients with neoplasia. Biochim. Biophys. Acta. 662:173180.

26. Troen, B. R., D. Ascherman, D. Atlas, and M. M. Gottesman. 1988. Cloning and expression of the gene for the major excreted protein of transformed mouse fibroblasts: a secreted lysosomal protease regulated by transformation. $J$. Biol. Chem. 263:254-261.

27. Eakin, A. E., J. Bouvier, J. A. Sakanari, C. S. Craik, and J. H. McKerrow. 1990. Amplification and sequencing of genomic DNA fragments encoding cysteine proteases from protozoan parasites. Mol. Biochem. Parasitol. 39:1-8.

28. Diamond, L. S., D. R. Harlow, and C. C. Cunnick. 1978. A new medium 
for the axenic cultivation of Entamoeba histolytica and other Entamoeba. Trans. R. Soc. Trop. Med. Hyg. 72:431-432.

29. Robinson, G. L. 1968. The laboratory diagnosis of human parasitic amoebae. Trans. R. Soc. Hyg. Trop. Med. Hyg. 62:285-294.

30. Huber, M., L. Garfinkel, C. Gitler, D. Mirelman, M. Revel, and S. Rozenblatt. 1987. Entamoeba histolytica: cloning and characterization of actin cDNA. Mol. Biochem. Parasitol. 24:227-235.

31. Chomczynski, P., and N. Sacchi. 1987. Single-step method of RNA isolation by acid guanidinium thiocyanate-phenol-chloroform extraction. Anal. Biochem. 162:156-159.

32. Torian, B. E., B. M. Flores, V. L. Stroeher, F. S. Hagen, and W. E. Stamm. 1990. cDNA sequence analysis of a 29-kDa cysteine-rich surface antigen of pathogenic Entamoeba histolytica. Pro. Natl. Acad. Sci. USA. 87:6358-6362.

33. Church, G. M., and W. Gilbert. 1984. Genomic sequencing. Proc. Natl. Acad. Sci. USA. 81:1991-1995.

34. Edman, U., I. Meza, and N. Agabian. 1987. Genomic and cDNA actin sequences from a virulent strain of Entamoeba histolytica. Proc. Natl. Acad. Sci. USA. 84:3024-3028.
35. Sambrook, J. C., E. F. Fritsch, and T. Maniatis. 1989. Molecular Cloning: A Laboratory Manual. 2nd ed. C. Nolan, editor. Cold Spring Harbor Press, Cold Spring Harbor, New York.

36. Matsudaira, P. 1987. Sequence from picomole quantities of proteins electroblotted onto polyvinylidene difluoride membranes. J. Biol. Chem. 262:10035-10038.

37. Eakin, A. E., A. A. Mills, G. Harth, J. H. McKerrow, and C. S. Craik. 1992. The sequence, organization, and expression of the major cysteine protease (cruzain) from Trypanosoma cruzi. J. Biol. Chem. 267:7411-7420.

38. Orozco, E. 1992. Pathogenesis in amebiasis. Infectious Agents and Disease. 1:19-21.

39. De Meester, F., E. Shaw, H. Scholze, T. Stolarsky, and D. Mirelman. 1990. Specific labeling of cysteine proteinases in pathogenic and nonpathogenic Entamoeba histolytica. Infect. Immun. 58:1396-1401.

40. Orozco, E., M. A. Rodriguez, and F. Hernandez. 1988. The role of phagocytosis in the pathogenic mechanism of Entamoeba histolytica. In Amebiasis: Human Infection by Entamoeba histolytica. J. I. Ravdin, editor. John Wiley and Sons, New York. 326-338. 